\title{
Viewing Scenes of the History of Chemistry through the Opera Glass
}

\author{
João Paulo André \\ Centro/Departamento de Química, Campus de Gualtar, Universidade do Minho, 4710- \\ 057 Braga, Portugal
}

Email: jandre@quimica.uminho.pt

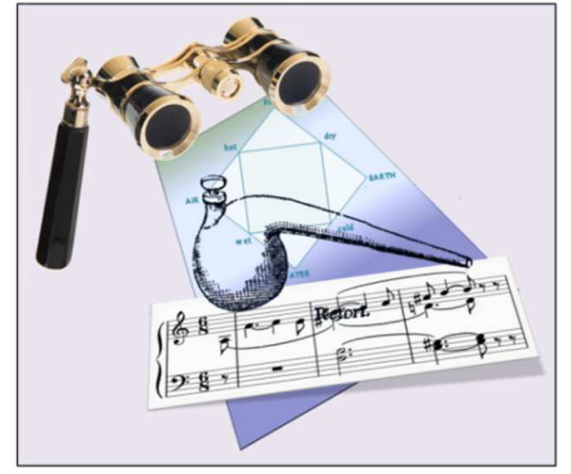

\begin{abstract}
Artistic creation has always reflected the spirit of the moment and opera has not been an exception. There are several examples of operas which appeared at key moments of the development of science, portraying them. Additionally there are also operas that emerged after scientific events or the lifetime of the scientists they were inspired on. In what concerns chemistry, the first category could be exemplified by the apothecary operas (already discussed by the author in a previous paper of this journal) while the others could be illustrated by recent operas such as Dr. Atomic or Madame Curie.

Continuing our endeavor of establishing relations between opera and chemistry, and considering that history of science plays an important role in the process of teaching and learning sciences, some milestones of the history of chemistry are here revisited through the opera glass. The operas analyzed have been grouped in the following categories: Operas of Fire and Metallurgy, Operas of the Philosophers of Antiquity, Operas of Alchemy, Operas of the Age of Enlightenment, Operas of the Revolutions and Operas of Entropy.
\end{abstract}


Keywords: General Public; High School/Introductory Chemistry; First-Year Undergraduate/General; Continuing Education; History/Philosophy; Interdisciplinary/Multidisciplinary; Multimedia-Based Learning; Metallurgy

\section{Introduction}

The relationships between chemistry and opera based on poison and potions have been exploited in a paper published in this journal. ${ }^{1}$ This paper has led others to say, certainly not without a sense of humor, that a new type of categorization of operas is now possible: according to their molecular content. ${ }^{2}$ Continuing the project to establish bridges between opera and chemistry, more operas are here presented and discussed in view of their potential value as vehicles for the introduction of topics of history of chemistry in the classroom or to the general public. Opera and science - particularly chemistry - not infrequently have experienced a parallel and simultaneous existence over the times. This has been illustrated in the previous paper through examples such as the apothecary operas (which appeared more or less simultaneously with Carl Scheele's great contributions to chemistry in the second half of the $18^{\text {th }}$ century) or the arsenic operas (with emphasis on the fact that during the $19^{\text {th }}$ century England went through a global scale intoxication with arsenic, mainly due to wallpaper dyes). Additionally there are many other operas whose action takes place in critical periods of the history of science, and of chemistry in particular. In this paper we focus on some particular moments of the history of chemistry through the opera glass. This might be appealing to teachers and educators who believe in the importance of history of chemistry as an important pedagogical piece in the process of teaching and learning chemistry. ${ }^{3-7}$

In this paper, if not stated differently, the sources of information on the quoted operas have been the librettos that normally accompany the existing commercial recordings 
and The New Grove Dictionary of Opera. Table 1 presents a selection of arias and scenes of some of the operas that are mentioned throughout this paper.

\section{Operas of Fire and Metallurgy}

Since the moment, lost in the mist of time, when humans saw lightening crossing the sky and igniting wood, they learned that fire is a transforming agent of matter. Later, they also learned that fire could melt metallic ores. Metallurgy, the extraction of metals from ores and the working of metals, was thus created..$^{8,9}$

According to Greek mythology, fire originally belonged only to the gods, but it was robbed by the Titan Prometheus who gave it to humanity, enabling progress and civilization. For this infraction, Zeus sentenced Prometheus to eternal torment: he was bound by Hephaestus (the Greek god of metallurgy) to a rock where each day an eagle was sent to feed on his liver, which would then grow back the next day. This myth inspired several musical compositions, including operas among which stand out Gabriel Fauré's Prométhée (1910) and Carl Orff's Prometheus (1968).

The invention of metallurgy represents an achievement of such significance that early human time is divided by historians into ages associated with the metal that humans could obtain at that time: for Western civilization, the Copper Age represents the period from 6000 to $3000 \mathrm{BC}$ and the Bronze Age the period between 3000 and $1200 \mathrm{BC}$. Eventually, when furnaces were able to sustain higher temperatures for the reduction of the iron ores, came the Iron Age, which in Europe continued until 400 AD. ${ }^{10,11}$

When using opera as a motivating tool for the introduction of chemical aspects of metallurgy, the "Anvil chorus" from Act II of Verdi's II Trovatore (1853) might be a good choice considering the beauty and the power of its music. If one wishes to go deeper into this subject, there is Charles Gounod's opera La Reine de Saba (The Queen of Sheba, 1862) which includes the once famous tenor aria "Inspirez moi race divine". In this aria the hero invokes the sons of Tubal-Cain, the biblical founder of metalworking ${ }^{12}$, as the molten metal flows into its mould. 
The first metals that caught man's attention were surely those that could be found in nature and exhibit prominent physical properties, such as native gold with its intrinsic color and shine. Gold is a metal that naturally occurs as minuscule particles in the primary quartz veins in which it is formed (primary gold). In those cases the deposits have been eroded, the metal can be released and reconcentrated by the action of water and thus deposited in beds of sands or gravels (secondary or placer gold). ${ }^{13}$ As early as $4000 \mathrm{BC}$, in Eastern Europe, gold began to be used to fashion decorative objects. The metal has probably been mined in the Transylvanian Alps or the Mount Pangaion area in Thrace (on the modern borders of Bulgaria, Greece, and Turkey). Later on, around $1200 \mathrm{BC}$, the Egyptians were already able to master the art of beating gold into leaf and of alloying it with other metals, for hardness and color variations. ${ }^{14}$ Croesus, the legendary king of Lydia (a kingdom in nowadays Anatolia, Turkey) had an immense richness due to the extraction of gold from the sands of the Pactolus River which, according to the myth, king Midas had touched. The coins of Lydia were initially produced from electrum, a natural alloy of gold and silver in a composition similar to that of the alluvial materials found in the Pactolus. Around the year $560 \mathrm{BC}$, already during Croesus reign, the first coins made purely from gold were minted, which obviously required the capability of purifying gold. For this purpose, the finally divided naturally occurring electrum, in the presence of sodium chloride, was heated to $800^{\circ} \mathrm{C}$, allowing the removal of silver through the formation of silver chloride (a process known as cementation $\left.{ }^{15}\right)$. Some coins of the reign of Croesus can still be seen at the British Museum in London. ${ }^{13}$ The life and legend of Croesus inspired several operas, among them Rheinhard Keiser's Croesus (1711). The historical background of this opera's action is the defeat of Croesus by the Persian king Cyrus.

In the past, gold-containing sand used to be washed and graveled over a woollen fleece as the smaller particles tend to stick to the natural lanolin of the fibers. After drying the fleece this was burned in a high-temperature fire and the gold dust melted into drops that were easily separated from the ashes. ${ }^{16}$ This method for exploiting 
alluvial gold is the basis for the Greek legend of Jason and the Argonauts, who sailed from Greece in quest of the Golden Fleece. The tragic love story of Jason and Medea is told in several operas, among which Luigi Cherubini's Medea (1797) excels.

The quest for gold in opera is probably best represented by Giacomo Puccini's La Fanciulla del West (1910), as its action takes place during the California Gold Rush (1848-1855). It includes several roles for gold miners and the score has many parts inspired on traditional American tunes. This opera certainly will thrill the audience and there are several excellent productions available on DVD.

Das Rheingold (The Rhine Gold, 1869), the first of the four operas of Richard Wagner's cycle The Ring of the Nibelung, can be included in this category of metallurgic operas as its story, a story of ambition of power, is centered on the magic ring made with the gold of Rhine's river. It is a ring that will allow its bearer to rule the world if he renounces to love. At the end of scene 2, when Wotan and Loge descend into Nibelheim, a choir of anvils beats out the dotted rhythm of the Nibelung theme. This opera will be further discussed in the section Operas of Alchemy. In Siegfried (1876), the third of the four operas of The Ring of the Nibelung, the dwarf Mime, who wants the ring for himself, is unsuccessfully trying to repair a sword for Siegfried to kill the dragon that guards the ring. Later on it will be Siegfried himself who forges the sword Notung. In act II of Hector Berlioz's opera Benvenuto Cellini (1838), loosely based on the memoirs of the Florentine sculptor Benvenuto Cellini, the protagonist casts a bronze statue of Perseus in the presence of the Pope, who has commissioned it. The opera ends in praise of the metal workers.

Last but not least, Carl Maria von Weber's Der Freischütz (1821) includes in act II the fantastic Wolf's Glen scene in which seven magic bullets are cast on stage.

\section{Operas of the Philosophers of Antiquity}

The ancient Greek philosophers of the Atomist School developed a systematic and comprehensive natural philosophy accounting for the origins of matter, anticipating that 


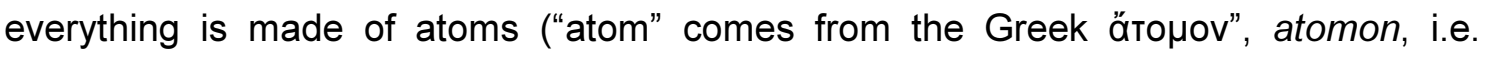
indivisible). The two most preeminent thinkers of this school were Leucippus (first half of $5^{\text {th }}$ century $\mathrm{BC}$ ) and his disciple Democritus (c. 460 - c. $\left.370 \mathrm{BC}\right) .{ }^{17}$ Democritus has been the source of inspiration of no less than three operas: Der Lachende Democritus (The Laughing Democritus, 1703) by Georg Philipp Telemann, Democrito corretto (Democritus Corrected, 1787) by Carl Ditters von Dittersdorf and Eraclito e Democrito (Heraclitus and Democritus, 1795) by Antonio Salieri. In the latter opera, against all odds, Democritus is joined by Heraclitus (c. 535-c. 475 BC) in what is described as an opera filosofico-buffa. Its plot makes fun of the addiction of a father to philosophy and his wish to marry his daughter to one of the two philosophers, an aspiration that he fails to realize. The overture contrasts the laughing Democritus with the gloomy Heraclitus. Also in the pre-Socratic school of philosophy, Empedocles of Agrigentum (490-430 BC) developed the cosmogenic theory of the four classical elements: air, water, fire and earth. The elements were considered themselves to be composed of very small and immutable particles, according to the atomic theory of Leucippus. Another example is provided by Empedocles (1995), a "dance opera" conceived as a music-film, with music and libretto by Robert Robertson, featuring episodes from the life of the early Greek philosopher.

Empedocles was a follower of Pythagoras (c. 570 BC - c. 495 BC), hence a believer in the transmigration of souls. There are several reports of his death which more or less agree on the fact that he threw himself into a volcano to prove to his disciples that he was immortal as he believed he would come back as a god after being consumed by fire. According to some of the reports his intentions were frustrated as one of his bronze sandals was seen to be thrown up by the volcano. ${ }^{18,19}$

The elements have been a strong inspiring theme for several musical scores, opera included, especially in the baroque period. Les Élémens (The Elements, 1721) is an opera-ballet by the French composer André-Cardinal Destouches (a disciple of Lully) that includes an overture depicting the birth of the elements. In its première some 
dance solos were interpreted by King Louis XV himself. Another opera of that time is Los Elementos - Opera Armonica al estilo Italiano (1718), composed by the Spanish Antonio de Literes. Interestingly these operas of the elements led Alvarez to point out that one can "speculate about a possible correspondence between the four material elements and the four elements of musical composition: rhythm, melody, harmony and timbre". ${ }^{20}$

\section{Operas of Alchemy}

European alchemy (introduced during the $10^{\text {th }}-11^{\text {th }}$ centuries) is related, in a temporal sequence, to Arabic alchemy, Greek alchemy and Egyptian alchemy (this latter began around $5000 \mathrm{BC}){ }^{9}$ With time, alchemy became a discipline with two main objectives: the transmutation of cheaper metals into gold (to be achieved with a philosopher's stone) and the preparation of the elixir of life, which would make humans younger, thus delaying death. ${ }^{9}$ True alchemists believed that practicing alchemy would not only lead to the transmutation of the metals but it would also be capable of driving themselves from a state of crudeness to a superior state of perfection. ${ }^{21}$ Transmutation always existed in nature in radioactive elements and, as Calado has remarked, for some of these elements, the disintegration series ironically ends with the formation of lead, one of the cheapest metals of alchemists. ${ }^{22}$

By the end of the $16^{\text {th }}$ century, another kind of transmutation occurred in Florence, Italy, due to the Camerata Fiorentina, a group of humanists, musicians, poets and intellectuals. This transmutation was not alchemical by any means, despite the fact that the composer Claudio Monteverdi, himself a practicer of alchemy, was among the members of the Camerata. ${ }^{23}$ It was in fact a musical and theatrical transmutation that, setting its roots on the classical Greek drama, eventually changed the western civilization's culture: opera was born!

The subject of the elixir of life has attracted composers of all eras but probably it has never been better musically epitomized than in Věc Makropulos (The Makropulos 
Affair, 1926), the opera of Leoš Janáček that is a metaphor about the meaning of life and the inevitable human physical decay. The action of this drama is set in 1912 and the protagonist is Elina Makropulos, a woman born in 1585. Her father was an alchemist who invented an elixir of life which he tried out on her. In 1912 the effect of the elixir is inexorably vanishing and she needs another dose to be able to live a further three centuries.

The baroque composer Marc-Antoine Charpentier (1643-1704) was also attracted by the subject of alchemy. He composed the "musique de scène" for La Pierre Philosophale (1681), a comedy of Thomas Corneille and Jean Donneau de Visé that features two main characters searching for the philosopher's stone. This piece comprises the alchemic elementals of Paracelsus (1493-1541), which are gnomes (spirits of earth), salamanders (spirits of fire), undines (spirits of water) and sylphs (spirits of air). ${ }^{24}$ The score includes a choir of the four elements and a duo for fire and water that states that the strength of love is capable of unifying the oposites. ${ }^{20,25}$ The list of operas which contain alchemic elementals is not short being one of the most appealing examples Antonín Dvořák's Rusalka (1901). This is a lyric fairytale inspired by Slavic mythology telling the story of an undine who falls in love with a human prince (it includes the famous "Song to the Moon"). Operas like Wagner's Das Rheingold, with the three Rhinemaidens as guardians of the gold, and Alfredo Catalani's Loreley (1890) were inspired by Germanic folk culture and their stories are set on the Rhine.

Claude Debussy's Pelléas et Mélisande (1902) can be added to this inventory. This opera creates a dream-like atmosphere that comprises several aquatic references: Golaud finds Mélisande by a spring in the forest; she has lost her crown in the water; they marry but she falls in love with Pelléas (Golaud's brother), who she met by the fountain where she loses her wedding ring. Her recurrent tears may also be part of this set of aquatic connotations. Additionally, the name of Mélisande brings to mind Mélusine, a spirit of water in sacred springs and rivers with a half-human, half-animal body. She was a heroin of medieval European romances of chivalry, in particular in 
France. ${ }^{26}$ Nowadays she is depicted in the green and white symbol of a worldwide known coffee brand. Under the title of Undine there are also the operas of Albert Lortzing (1845), E. T. A. Hoffmann (1816) and Pyotr llyich Tchaikovsky (composed in 1869 but partially destroyed by the author in 1873).

There are a few dozen operatic adaptations of The Tempest (1611), the last play of William Shakespeare. Curiously (contemporary opera usually does not please the general public!) the most popular is probably the most recent one: Thomas Adès's The Tempest (2004). The Tempest has a great plot with ingredients including conspiracy, vengeance, love and forgiveness. The story takes place on a magic island where Prospero and his daughter Miranda find shelter after several years adrift on a ship, following a political treason. Prospero, possessing magic powers due to his great knowledge, which includes alchemy, and with the help of Ariel - a spirit that metamorphoses in air, water and fire - creates a tempest and a shipwreck that brings his enemies to the island. The magus, a sort of alchemist and magician, was a recurrent character at the time of Shakespeare's The Tempest. The English comedy The Alchemist (1610) by Ben Jonson, a rival of Shakespeare, had premiered just one year before The Tempest but Prospero might have been inspired by real personages such as Paracelsus, John Dee (an astronomer, astrologer, occultist, alchemist and consultant to Queen Elizabeth I) or Faust from Christopher Marlowe's play Doctor Faustus (1594), based on old Germanic tales about a certain Faustus who practiced esoteric sciences. ${ }^{27}$ In Oberon (1826), a romantic opera with spoken dialogue and music by Carl Maria von Weber, with a similar plot to that of The Tempest, the character Puck also invokes the elementals to wreck a ship.

The figure of the alchemist appears in several other operas. The following examples are worth special attention: Der Alchymist (1778), a comic piece by Joseph Schuster; Der Alchymist (1830), by Ludwig Spohr and based on Washington Irving's tale The Student of Salamanca; The Alchemist (1917-18), by Cyril Scott, celebrating the 
superiority of spiritual over material wishes ${ }^{28}$ and Richard Strauss's Feuersnot (1901), in which the protagonist Kunrad is a medieval magus/alchemist.

In this category of operas, the most popular one is undoubtedly Charles Gounod's Faust (1859), based on Johann Wolfgang von Goethe's Faust, Part 1 (1808). ${ }^{29}$ It plays in $16^{\text {th }}$ century Germany and alchemy is central to its dramatic conception (Goethe himself had early in his life extensively studied alchemical literature). Faust is an aging scholar and scientist who, rebelling against science and faith on realizing that his studies and research had come to nothing, only serving to keep him away from enjoying life and love, is about to kill himself with poison. Faust invokes then the devil, which appears as Mephistopheles promising youth. The myth of Faust has attracted other opera composers, including Ludwig Spohr (Faust, 1816), Hector Berlioz (La Damnation de Faust, 1846), Arrigo Boito (Mefistofele, 1868), Ferrucio Busoni (Doktor Faust, 1925) or Giacomo Manzoni (Doktor Faustus, 1989, this one based on Thomas Mann's novel).

Act I of Jacques Offenbach's opera The Tales of Hoffmann (1881) was partially based on The Sandman (1816), a short story by E.T.A. Hoffmann of an extravagant terror characteristic of the German romantic period. The father of the protagonist, Nathanaël, is an alchemist who dies in an explosion in his laboratory. ${ }^{30}$ In the opera, Hoffmann is the main character and his first love is Olympia, a mechanical doll created by Spalanzani, a sort of alchemist. Olympia's aria "Les Oiseaux..." is quite attractive, especially for its acrobatic vocal effects. The opera also includes the quite famous "Diamond aria" which celebrates an allotrope of carbon.

To end this list of alchemical operas one should not forget that in Donizetti's L'Elisir d'Amore (1832) the quack Dr. Dulcamara describes the powers of his miraculous elixir using a vocabulary quite reminiscent of alchemy.

\section{Operas of the Age of Enlightenment}


In the age of Enlightenment, which began in the late $17^{\text {th }}$ century, reason and individualism were emphasized in detriment of superstition and intolerance. The intent was to reform society through skepticism and reason. For this purpose it was essential to defy ideas based on tradition and faith and to advance knowledge with scientific means. Accordingly, chemistry is usually said to have set its modern foundations as early as 1661 with the publication of Robert Boyle's The Sceptical Chymist, defending the idea that matter consisted of atoms and clusters of atoms in motion and defining the chemical element. In truth, twenty years earlier the French Étienne de Clave had already proposed a definition of element similar to Boyle's ${ }^{31}$ During the last decades of the $18^{\text {th }}$ century, Carl Scheele, in Sweden, made remarkable contributions to the development of chemistry and, simultaneously, Haydn premiered his opera Der Apotheker (1768). The apothecary operas have been the subject of a deeper analysis in a previous paper. ${ }^{1}$

In spite of the scientific advancements attained in the late $17^{\text {th }}$ and $18^{\text {th }}$ centuries, alchemy still had many followers, among them eminent scientists such as Robert Boyle himself and Isaac Newton..$^{9,32-33}$ The world of alchemy actually would not be totally strange to Wolfgang Amadeus Mozart, as he had been commissioned to compose an opera during his visit to Vienna in 1768 , at the age of 12 , by the Viennese physician Franz Anton Mesmer (1734-1815), a mason and friend of the alchemist Giuseppe Balsamo (1743-1795). The result of Mozart's assignment was Bastien und Bastienne, a Singspie/ with a libretto based on the work of Rousseau, Le Devin du Village (1752), in which the character Colas is a diviner and alchemist.

Franz Mesmer claimed to have discovered the invisible life-force that animated matter, which he called animal magnetism. ${ }^{34}$ The "medical" application of this magnetism became known as mesmerism. ${ }^{35}$ Not innocently, at the end of act I of Cosi fan tutte (1790) Mozart made a parody of Mesmer. This happens when the maid Despina, disguised as a doctor, uses the "pietra mesmerica" (mesmeric stone) to "cure" the two fake Albanians who claim to have been poisoned with arsenic. ${ }^{28,34}$ Despite being 
somehow out of the scope of this text it is nevertheless interesting to note that Mesmer was eventually banned from medical practice in Paris. This occurred in 1784 after an investigation by a commission that included luminaries such as Antoine Lavoisier and Joseph-Ignace Guillotin (an expert in pain who actually did not invent the guillotine, just recommended its use for capital punishment). ${ }^{28,36}$ It is also worth mentioning that JeanPaul Mara, a keen defensor of mesmerism, contributed significantly to the condemnation of Lavoisier to death by guillotine.

In terms of chemistry, mesmerism was linked to vitalism (the explanation that living things are alive due to some special vital force). In 1828, in a quite unexpected opposition to this doctrine, Friedrich Woehler described the synthesis of urea in his laboratory. Having started from inorganic precursors such as cyanic acid (HNCO) and ammonia, Woehler demonstrated that there was no chemical barrier between animal and vegetable realms. ${ }^{36-38}$

Despite the discredits of Mesmer, by the 1820's his theories managed to be partially rehabilitated in association to phenomena such as hypnotism, somnambulism and dementia, ${ }^{39,40}$ which eventually became subjects of enormous interest to the general public. Considering these aspects, certainly it was not a coincidence that Bellini's opera La Sonnanbula premièred in 1831 (at the time many other operas on the subject of somnambulism had appeared). Giuseppe Verdi's Macbeth (1847), based on Shakespeare's tragedy, includes the famous "Sleepwalking Scene" of Lady Macbeth. If one has to illustrate dementia in opera, apart from Giovanni Paisiello's Nina, o sia La Pazza per Amore (1789) there is the ultimate example of Gaetano Donizetti's Lucia di Lammermmor (1835). Its "Mad Scene" was originally intended to be accompanied by the sound of a glass harmonica, an instrument that Mesmer himself used for his "therapies" ${ }^{41}$ Nowadays, this scene is commonly performed with two flutes but at the Metropolitan Opera House, in 2009, a glass harmonic was used to accompany Anna Netrebko in the title role. Donizetti's choice of the glass harmonic was not entirely innocent since this instrument is made of lead crystal, a glass that contains $18-40 \%$ by 
weight of lead(II) oxide. Lead is a metal that is well known to be associated to dementia. ${ }^{42}$

In the age of Enlightenment, and even later, only the wealthy people could perform chemistry, usually in their private laboratories. In opera this is illustrated by the Prince de Bouillon in Francesco Cilea's Adriana Lecouvreur (1902). His aria "Candida, lieve come la neve" refers to the poison arsenic trioxide (known in France as "inheritance powder").

\section{Operas of the Revolutions}

This topic leads us immediatly to Antoine Lavoisier but unfortunatelly, as far as we know, there is no opera in which he is featured (despite Carl Djerassi and Roald Hoffmann's play Oxygen (2001)). In opera, the closest to Lavoisier one can find is Umberto Giordano's Andrea Chénier (1896), inspired by the life of the French poet André Chénier (1762-1794) who, like Lavoisier, had been guillotined in 1794, near the end of the French Revolution period known as "The Terror". Their fate was not the only aspect that they shared. In fact, as both belonged to the Tout-Paris obviously they knew each other, being habitués of the same salons, including those of Chénier's mother and Mme. Lavoisier. Chénier had studied with Charles Louis and Charles Michel Trudaine, the sons of Philibert Trudaine de Montigny. The three friends shared eventually the same final destiny, all being sentenced to death in $1794 .{ }^{43,44}$ Trudaine de Montigny was a person of very high rank in the State and himself a prominent chemist, member of the Academy of Sciences and friend of Lavoisier. For his high duties to the French State, Trudaine de Montigny made use of the scientific espionage of João Jacinto de Magalhães, a famous Portuguese spy internationally known as Jean Hyacinthe de Magellan. In 1772 Trudaine de Montigny received from him a report containing details of the experiments of Priestley on impregnating water with fixed air $\left(\mathrm{CO}_{2}\right)$. Montigny described the contents of this report to Lavoisier, encouraging him to repeat the experiments. This proved to be of major importance for the work of Lavoisier 
which, in due course, culminated in the discovery of oxygen, almost simultaneously with Priestley and Schelle. ${ }^{22,45,46}$

Meanwhile, society and science have evolved and Alessandro Volta's pile, the first electrochemical cell, reported in 1800, would soon allow William Nicholson and Anthony Carlisle to perform the electrolysis of water. ${ }^{47-48}$ By this time, with the execution of many of the prominent French chemists during The Terror, the center of chemical research had moved to Britain. This became the era of great British chemists, such as John Dalton and Humphry Davy. Davy, who performed the electrolysis of molten salts, succeeded in isolating potassium and sodium in 1807 and barium, strontium, calcium and magnesium in 1808. ${ }^{49-51}$ The public lectures/demonstrations of Humphry Davy at the Royal Institution, which started in 1801, had quite a strong impact on spectators. Jane Marcet and her husband, the medical doctor and chemist Alexander Marcet, were often present in the audience. Jane was so impressed with those sessions that she decided to write Conversations on Chemistry (1805), a book especially dedicated to the education of women in chemistry. ${ }^{52-55}$ Michael Faraday was a young bookbinder apprentice when he read the book, which later he recalled as having formed the basis of his knowledge on chemistry and electricity ${ }^{56}$ Conversations, a best seller in several languages, influenced the education of several generations to the extension that by the end of the century Jane Marcet was still mentioned in Henry James's novel The Turn of the Screw (1898). ${ }^{57}$ This novel later on inspired Benjamin Britten to compose the eponymous opera (1954).

Jacques Offenbach's comic opera Le Docteur Ox (1877), based on Jules Verne's novel Une fantaisie du docteur Ox (1874), tells the story of a certain Dr. Ox who was testing a new gas lighting system in a city where everything happened at a very slow pace - from the biological processes to the courtship (which could take up to ten years!). In the city's opera house, Rossini's aria "Largo al factotum della cità!" from // Barbiere de Sevilla (1816) would take almost one hour instead of the usual four to five minutes. In fact, Dr. Ox was secretly interested in testing the effect of the new gas (oxyhydric gas, 
as it was named) on living beings. The gas, obtained by passing electric current through water, was channeled into the city and soon shown to cause accelerated growth in plants and excitement and aggressiveness in people and animals. Not surprisingly, the story ends with the explosion of the gas factory due to the combination of the two gases obtained from water.

Patience (1881), the comic opera of Gilbert and Sullivan, was the first theatrical production in the world to be entirely lit by electric light. Furthermore, in the context of electricity, Giacomo Puccini's Scossa Elettrica (Electric Shock, 1899), a very animated march specially composed for the "International Convention of Telegraphists" held in Como, Italy, as part of the celebrations of the centenary of Volta's cell, deserves to be mentioned (and heard!). ${ }^{58}$

\section{Operas of Entropy}

The concept of entropy, introduced in 1865 by Rudolf Clausius, is the key concept of the second law of thermodynamics. In the present context it is fair to quote A. T. Schwartz, who stated that "The second law [of thermodynamics] seems to drive Shakespeare's tragedies: entropy runs wild in King Lear". Reminding us of Othello's famous announcement "chaos is come again", Schwartz defends that "Shakespeare's understanding of natural, spontaneous change was as profound as that of Carnot, Clausius, and Boltzmann" ${ }^{59}$

At the beginning of the $20^{\text {th }}$ century Arnold Schoenberg and his disciple Alban Berg were responsible for the musical evolution from the tonal to the atonal system. Atonality may be seen by some as the musical equivalent to the effects of the second law of thermodynamics. In dodecaphonism, a later form of atonality, all twelve tones of the chromatic scale are given more or less equal importance so the music avoids being in a key. In tonal music there is an overlap of the upper harmonics of the notes, which, when sounding together, create a pleasant sense of consonance while in atonal music harmonics do not overlap, thereby creating a sense of dissonance. In tonal music there 
is an environment of restricting harmonic rules, of lower entropy, whereas atonal music allows an environment of less restriction, and consequently of higher entropy. ${ }^{60}$ Alban Berg's dodecaphonic opera Lulu (1937) is a good example of entropy in opera. Not only the atonal score contributes to this but also the plot itself, which features characters such as Jack the Ripper and comprises an entire set of sordid themes that range from murder to prostitution and sexually transmitted diseases. Probably not only the ears of the audiences of that era felt uncomfortable with atonality as moral values may also have been shaken. The libretto of Lulu is based on Frank Wedekind's play Die Büchse der Pandora (Pandora's Box, 1904). It metaphorically recalls the myth of Pandora, which in turn also contains an elevated entropic content: Pandora, not able to ignore her curiosity, opened the box Zeus had given her under the condition that it should not be opened. Out of it escaped, irreversibly, all the bad things of the world. The genius of Marie Curie, (co)discoverer of radioactivity and of the two radioactive elements polonium and radium, was operatically celebrated in 2011 (the International Year of Chemistry) through Madame Curie, an opera by Elzbieta Sikora. Also in recent years, Dr. Atomic (2005), the spectacular and touching opera of John Adams featuring Robert Oppenheimer in the main role, told us the dramatic psychological atmosphere arising from the Trinity Test, in Los Alamos, New Mexico, in 1945. This opera constitutes a good opportunity for teachers and educators to address the subject of nuclear fission and the issue of ethics in science.

In October 2013, Julian Wagstaff's chamber opera Breathe Freely premiered in Edinburgh. This piece was commissioned by the University of Edinburgh to celebrate the $300^{\text {th }}$ anniversary of its School of Chemistry, where illustrious chemists such as Joseph Black (discover of carbon dioxide gas and latent heat) have taught. The opera is set in Edinburgh in the closing stages of the Second World War and is based on a book of the same name written by James Kendall in 1938 on the subject of chemical weapons. Breathe Freely addresses moral issues surrounding the role of scientists in war and peacetime. ${ }^{61,62}$ 
In order to finish this text with a certain smile let's remember the end of act II of Wagner's Die Meistersinger von Nürnberg (The Mastersingers of Nuremberg, 1868) which is quite rich in entropy. The noisy hammering of the cobbler Sachs, accompanying the chaotic serenade of Beckmesser, awakes the entire neighborhood and the situation degenerates into a full-blown public disturbance. Another amiable example of entropy in opera is provided by Benjamin Britten's Midsummer's Night's Dream (1960), based on Shakespeare's play. It includes confused identities such as an ass's head on the body of the weaver Bottom and other examples of a certain level of general confusion. Entropy runs riot in the story until Maxwell's Demon ${ }^{63}$ in the guise of the character Puck, finally restores order.

\section{Conclusion}

Often opera is not an easily understood nor appreciated musical art form, especially for younger audiences. Opera however can be an effective pedagogical tool if properly presented and used in the classroom or in continuing education. This article summarizes some ideas of how the relationships between opera and chemistry can be exploited for pedagogical purposes. In addition to the more obvious chemical and toxic aspects related to the poisons frequently found in opera plots, opera can also be employed as a means of illustrating many key moments of the history of chemistry. This is relevant in view of the role that history of chemistry may play in teaching and learning chemistry.

\section{Acknowledgments}

The author is pleased to express his gratitude to Jorge Calado for inspiration, suggestions and useful discussions.

The reviewers of the manuscript are also thanked for their helpful comments and suggestions. 
Michael John Smith is acknowledged for resolving some linguistic difficulties and Mario Berberan e Santos for providing access to specific bibliography.

Federico M. Rubino is thanked for the information concerning the aria "Candida, lieve come la neve" from act III of Adriana Lecouvreur.

Thanks also due to the Foundation for Science and Technology (FCT-Portugal) and FEDER (European Fund for Regional Development)-COMPETE/QREN/EU for financial support through the research unity PEst-C/QUI/UI686/2013. 
Table 1 - Operas by Historical Category and Respective Scenes

\begin{tabular}{|c|c|c|}
\hline Opera (Composer) & Category & Aria or Scene \\
\hline \multicolumn{3}{|c|}{ Operas of Fire and Metallurgy } \\
\hline $\begin{array}{l}\text { Prometheus } \\
\text { (Orff) }\end{array}$ & & $\begin{array}{l}\text { Scene } 1 \text { "To the earth's } \\
\text { remotest" }\end{array}$ \\
\hline $\begin{array}{l}\text { La Reine de Saba } \\
\text { (Gounod)* }\end{array}$ & & $\begin{array}{l}\text { Aria "Inspirez-moi race } \\
\text { divine!", act II }\end{array}$ \\
\hline II Trovatore (Verdi) & & Anvil chorus", act II \\
\hline Croesus (Keiser) & & $\begin{array}{l}\text { Aria "Solon, weiser Solon", } \\
\text { act III }\end{array}$ \\
\hline Medea (Cherubini) & & $\begin{array}{l}\text { Aria "Dei tuoi figli la madre tu } \\
\text { vedi", act I. }\end{array}$ \\
\hline $\begin{array}{l}\text { La Fanciulla del West } \\
\text { (Puccini) }\end{array}$ & & $\begin{array}{l}\text { Aria and chorus "Che } \\
\text { faranno i vecchi miei", act I }\end{array}$ \\
\hline Das Rheingold (Wagner) & & $\begin{array}{l}\text { End of scene } 2 \text { (descent of } \\
\text { Wotan and Loge into } \\
\text { Nibelheim) }\end{array}$ \\
\hline Siegfried (Wagner) & & "Notung! Notung! Neidliches \\
\hline & & Schwert!", act I, scene 3 . \\
\hline Benvenuto Cellini (Berlioz) & & End of act II \\
\hline \multirow[t]{2}{*}{ Der Freischutz (Weber) } & & Wolf's Glen scene, act II \\
\hline & $\begin{array}{l}\text { Operas of the Philosophers of } \\
\text { Antiquity }\end{array}$ & \\
\hline $\begin{array}{l}\text { Der Lachende Democritus } \\
\text { (Telemann)* }^{*}\end{array}$ & & $\begin{array}{l}\text { Aria "Heutzutage macht das } \\
\text { Geld nur die Freunde in der } \\
\text { Welt" }\end{array}$ \\
\hline $\begin{array}{l}\text { Eraclito e Democrito } \\
\text { (Salieri)* }\end{array}$ & & Prelude \\
\hline Empedocles (R. Robertson) & & - \\
\hline \multirow[t]{2}{*}{$\begin{array}{l}\text { Les Éléments (A.-C. } \\
\text { Destouches) }\end{array}$} & & Overture \\
\hline & Operas of Alchemy & \\
\hline $\begin{array}{l}\text { The Makropulos Affair } \\
\text { (Janáček) }\end{array}$ & & Overture \\
\hline $\begin{array}{l}\text { La Pierre Philosophale } \\
\text { (Charpentier) }\end{array}$ & & $\begin{array}{l}\text { Choeur des Quatre } \\
\text { Elements }\end{array}$ \\
\hline Loreley (Catalani) & & $\begin{array}{l}\text { Aria "Amor, celeste } \\
\text { ebbrezza" }\end{array}$ \\
\hline $\begin{array}{l}\text { Pelléas et Mélisande } \\
\text { (Debussy) }\end{array}$ & & Prelude \\
\hline Rusalka (Dvořák) & & $\begin{array}{l}\text { Aria "Song to the Moon", act } \\
\text { I }\end{array}$ \\
\hline Oberon (Weber) & & $\begin{array}{l}\text { Aria "Ocean, thou Mighty } \\
\text { Monster", act II }\end{array}$ \\
\hline Der Alchymist (Spohr) & & $\begin{array}{l}\text { Recitative and Aria: "Ha! } \\
\text { Welch ein Plan!", act II: }\end{array}$ \\
\hline Faust (Gounod) & & $\begin{array}{l}\text { Aria "Ah! je ris de me voir si } \\
\text { belle en ce miroir"("Jewel } \\
\text { Song"), act III }\end{array}$ \\
\hline
\end{tabular}




\begin{tabular}{|c|c|c|}
\hline $\begin{array}{l}\text { The Tales of Hoffmann } \\
\text { (Offenbach) }\end{array}$ & & $\begin{array}{l}\text { Aria "Les oiseaux dans la } \\
\text { charmille" ("The Doll Song"), } \\
\text { act II and the "Diamond } \\
\text { aria", act III }\end{array}$ \\
\hline \multirow[t]{2}{*}{ L'Elisir d'Amore (Donizetti) } & & $\begin{array}{l}\text { Aria "Udite, udite, o rustici", } \\
\text { act I }\end{array}$ \\
\hline & $\begin{array}{l}\text { Operas of the Age of } \\
\text { Enlightenment }\end{array}$ & \\
\hline $\begin{array}{l}\text { Der Apotheker (or Lo } \\
\text { Spezialle) (Haydn) }\end{array}$ & & $\begin{array}{l}\text { Aria "Salamelica, } \\
\text { Semprugna cara", act III }\end{array}$ \\
\hline Così fan tutte (Mozart) & & $\begin{array}{l}\text { Aria "Eccovi il medico, } \\
\text { signore belle", act I }\end{array}$ \\
\hline La Sonnanbula (Bellini) & & $\begin{array}{l}\text { Aria "Ah, non credea mirarti", } \\
\text { act II }\end{array}$ \\
\hline $\begin{array}{l}\text { Lucia di Lammermmor } \\
\text { (Donizetti) }\end{array}$ & & $\begin{array}{l}\text { Aria "Il dolce suono...Spargi } \\
\text { d'amaro pianto" ("Mad } \\
\text { Scene"), act III }\end{array}$ \\
\hline Macbeth (Verdi) & & $\begin{array}{l}\text { Aria "Una macchia è qui } \\
\text { tuttora!" ("Sleepwalking } \\
\text { Scene"), act IV }\end{array}$ \\
\hline \multirow[t]{2}{*}{$\begin{array}{l}\text { Adriana Lecouvreur } \\
\text { (Cilea) })^{* * *}\end{array}$} & & $\begin{array}{l}\text { Aria "Candida, lieve come la } \\
\text { neve", act III ** }\end{array}$ \\
\hline & $\begin{array}{l}\text { Operas of the } \\
\text { Revolutions }\end{array}$ & \\
\hline Andrea Chénier (Giordano) & & $\begin{array}{l}\text { Aria “Un di all'azzurro } \\
\text { spazio”, act I }\end{array}$ \\
\hline \multirow[t]{2}{*}{$\begin{array}{l}\text { Le Docteur Ox } \\
\text { (Offenbach)* }\end{array}$} & & Overture \\
\hline & Operas of Entropy & \\
\hline Lulu (Berg) & & $\begin{array}{l}\text { Last scene (murders of Lulu } \\
\text { and the countess) }\end{array}$ \\
\hline Madame Curie (Sikora)* & & - \\
\hline Dr. Atomic (Adams) & & Aria "Batter my heart", act I \\
\hline Breathe Freely (Wagstaff)* & & - \\
\hline $\begin{array}{l}\text { Die Meistersinger von } \\
\text { Nürnberg (Wagner) }\end{array}$ & & End of act II \\
\hline $\begin{array}{l}\text { Midsummer's Night's Dream } \\
\text { (Britten) }\end{array}$ & & $\begin{array}{l}\text { Aria "Be Kind and } \\
\text { courteous", act II }\end{array}$ \\
\hline \multicolumn{3}{|c|}{$\begin{array}{l}\text { * These operas have not been (or only have been partially) recorded or currently are not } \\
\text { commercially available. }\end{array}$} \\
\hline \multicolumn{3}{|l|}{ ** Available on YouTube. } \\
\hline 110 & oluitias & \\
\hline
\end{tabular}

\section{References}

1 André, J. P. Opera and Poison: A Secret and Enjoyable Approach to Teaching and Learning Chemistry. J. Chem. Educ. 2013, 90, 352-357. 
2 Johnson, C. Y. The Boston Globe, April 07, 2013; http://www.bostonglobe.com/ideas/2013/04/06/treasury-operapoisonings/gKPw3zoiVNx7mZeRK1p0KL/story.html (accessed Jan. 2014)

3 Jaffe B. The History of Chemistry and its Place in the Teaching of High-school Chemistry. J. Chem. Educ. 1938, 383-389.

4 Jaffe B. Using the History of Chemistry in our Teaching. J. Chem. Educ. 1955, 183185.

5 Ihde, A. J. Let's Teach History of Chemistry to Chemists. J. Chem. Educ. 1971, 48, 686-687.

6 Stock, J. T. The Teaching of the History of Chemistry. J. Chem. Educ. 2004, 81, 793794.

7 Rasmussen S. C.; Patterson G. D. Introduction: The Humanity of Chemistry, in Characters. In Chemistry: A Celebration of the Humanity of Chemistry; Patterson, G. D.; Rasmussen, S. C., Eds; ACS Symposium Series; vol. 1136, 1-6, American Chemical Society: Washington, DC, 2013.

8 Ihde, A. J. The Pillars of Modern Chemistry. J. Chem. Educ. 1956, 33, 107-110.

9 Fabbrizzi, L. Communicating about Matter with Symbols: Evolving from Alchemy to Chemistry. J. Chem. Educ. 2008, 85, 1501-1511. 10 Hayward, C. R. Extraction of Metals From Ores. J. Chem. Educ. 1943, 29-32.

11 Mickey, C. D. Artistic Metalwork and Chemical Technology. J. Chem. Educ. 1981, $58,315-320$.

12 Coggins, R. Who's Who in the Bible, Batsford, London, 1981

13 Ramage, A.; Craddock, P. King Croesus Gold, British Museum Press, London, 2000 14 http://www.nma.org/pdf/gold/gold_history.pdf (accessed Jan. 2014)

15 Hiorns, A. H. Principles of Metalurgy, Forgotten Books, London, 2012.

16 http://mygeologypage.ucdavis.edu/cowen/ GEL115/115ch6.html (accessed Jan. 2014)

17 Guthrie, W. K. C. The Greek Philosophers, Routlege Classics, NY, 2013. 
18 Russel, B. History of Western Philosophy, Routledge, New York, 2013.

19 An opera fan teacher who wishes to exploit the chemistry of volcanic gases in the classroom can use the opera of Daniel Auber La Muette de Portici (The Dumb Girl of Portici, 1828) in which the protagonist, Fenella (mute role), throws herself into the Vesuvius during an eruption, not for the sake of glory as Empedocles but just out of desperation, in a context of love and nationalism (end of Act V "On vient! Silence, amis!"). An alternative is Giovanni Pacini's opera L' Ultimo giorno di Pompei (The Last day of Pompeii, 1825), a love story in the last day of the Roman city destroyed by the Vesuvius in $79 \mathrm{AD}$.

20 Alvarez, S. Music of the Elements. New J. Chem. 2008, 32, 571-580.

21 Holmyard, E. J. Alchemy, Penguin, Londres, 1957.

22 Calado, J. Haja Luz! - Uma História da Química Através de Tudo, IST Press, Lisbon, 2011.

23 Gilchrist, C. The Elements of Alchemy, Element Books, Rockport, MA, 1991.

24 Silver, C. G. Strange and Secret Peoples: Fairies and Victorian Consciousness, Oxford University Press, New York, 1999.

25 http://gallica.bnf.fr/ark:/12148/bpt6k72216t/f5.image (accessed Jan. 2014)

26 Maddox, D.; Sturm-Maddox, S. (eds) Melusine of Lusignan: Founding Fiction in Late Medieval France, University of Georgia Press, Athens, Georgia, 1996.

27 http://www.gutenberg.org/files/779/779-h/779-h.htm (accessed Jan. 2014)

28 Alvarez, S. Música Alquimística. An. Quím. 2009, 105, 142-150.

29 Goethe, J. W. von Faust Part 1, Penguin Books, London, 2005.

30 Hoffmann, E. T. A. Tales of Hoffmann, Penguin Books, London, 2004.

31 Alvarez S.; Sales, J.; Seco, M. On Books and Chemical Elements. Found. Chem. 10 (2008) $79-100$.

32 Debus, A. G. The Aspiring Adept: Robert Boyle and his Alchemical Quest, Including Boyle's "Lost" Dialogue on the Transmutation of Metals. Bulletin of the History of Medicine 1999, 73, 500-502. 
33 Newman, W. R. Promethean Ambitions: Alchemy and the Quest to Perfect Nature, University of Chicago Press, Chicago, 2004.

34 Till, N. Mozart and the Enlightenment, W. W. Norton \& Company, NY, 1993.

35 Herr, H.W. Franklin, Lavoisier, and Mesmer: Origin of the controlled clinical trial Urol. Oncol. 2005, 23, 346-351.

36 Jaffe, B. Crucibles: The Story of Chemistry, Dover publications, NY, 1976.

37 Warren, W. H. Contemporary Reception of Wohler's Discovery of the Synthesis of Urea. J. Chem. Educ. 1928, 5, 1539-1553.

38 Lipman, T. O. Wohler's Preparation of Urea and the Fate of Vitalism. J. Chem. Educ $1964,41,452-458$.

39 Braid, J. The Power of the Mind over the Body: An Experimental Inquiry into the Nature and Cause of the Phenomena Attributed by Baron Reichenbach and Others to a "New Imponderable". The Edinburgh Medical and Surgical Journal 1846, 66, 286311.

40 Riva, M. A.; Sironi, V. A.; Tremolizzo, L.; Lombardi, C.; De Vito, G.; Ferrarese, C.; Cesana, G. "Sleepwalking in Italian operas: a window on popular and scientific knowledge on sleep disorders in the 19th century" Eur. Neurol. 2010, 116-121.

41 Kennaway, J. "Musical Hypnosis: Sound and Selfhood from Mesmerism to Brainwashing", Soc. Hist. Med. (2011) http://shm.oxfordjournals.org/content/early/2011/10/05/shm.hkr143.full.pdf+html43 (accessed Jan. 2014)

42 Jacobs, D. E. Lead. Patty's Toxicology, 2012, 381-426; http://onlinelibrary.wiley.com/doi/10.1002/0471435139.tox034.pub2/pdf (accessed Jan. 2014)

43 Hanson, P. R. Historical Dictionary of the French Revolution, Scarecrow Press, Maryland, 2004. 
44 Blennerhassett, C. Madame de Staël: Her Friends, and Her Influence in Politics and Literature; https://archive.org/details/madamedestalher00unkngoog (accessed Jan. 2014)

45 Poirier, J.P. La Science et L'Amour: Madame Lavosier, Pygmalion, Paris, 2004.

46 Oesper, R. E. Priestley, Lavoisier, and Trudaine de Montigny. J. Chem. Educ. 1936, $13,403-412$

47 Stock, J. T. Electrochemistry in Retrospect, An Overview, chap.1, 1-17. In Electrochemistry, Past and Present, vol. 390, American Chemical Society, 1989.

48 Sheean, J. L. The Beginnings of Electrochemical Activities. J. Chem. Educ. 1930, 7, $33-42$.

49 Weeks, M.E. The Discovery of the Elements. IX. Three alkali Metals: Potassium, Sodium, and Lithium. J. Chem. Educ. 1932, 1035-1045.

50 Weeks, M.E. The discovery of the elements. Chronology. J. Chem. Educ. 1933, 223-227.

51 Kumar, V.; Milewski, L. Humphrey Davy: At the vanguard of a new chemistry. L. J. Chem. Educ. 1985, 62, 397-398.

52 Rayner-Canham, M. F; Rayner-Canham, G. W. Women in Chemistry: Their Changing Roles from Alchemical Times to the Mid-Twentieth Century, Chemical Heritage Foundation, Philadelphia, 2001.

53 Armstrong, E. V. Jane Marcet and her "Conversations on Chemistry. J. Chem. Educ. 1938, 15, 53-57

54 Crellin, J. K. Mrs. Marcet's "Conversations on Chemistry". J. Chem. Educ. 1979, 56, $459-60$

55 Marcet, J. Conversations on Chemistry, $5^{\text {th }}$ edition, Longman, London, 1817; http://www.gutenberg.org/files/26908/26908-h/26908-h.htm (accessed Jan. 2014) 56 de la Rive, A. Madame Marcet. Bibliothèque Universelle - Revue Suisse et Étrangère 1859, 64(4), 445-468. 
57 "She absolutely declined to be puzzled; she turned her eyes to the flame of the candle as if the question were as irrelevant, or at any rate as impersonal, as Mrs. Marcet or nine-times-nine.”. In James, H. Ghost Stories, Ware, Hertfordshire, 2001. 58 http://usatoday30.usatoday.com/life/music/2001-07-23-forgotten-music.htm (accessed Jan. 2014)

59 Schwartz; A.T. Chemistry Education, Science Literacy, and the Liberal Arts. 2007 Pimentel, G. C. Award. J. Chem. Educ. 2007, 84, 1750-1756.

60 Neeman, S.; Maharshak, A. Order and Disorder, Entropy in Math, Science, Nature and the Arts Engineering Studies Faculty Publications and Creative Works, 2006, Johnson \& Wales University; http://scholarsarchive.jwu.edu/cgi/viewcontent.cgi?article=1004\&context=engineering_f ac (accessed Jan. 2014)

61 http://www.chem.ed.ac.uk/about-us/tercentenary/tercentenary-events/breathefreely-chemistry-opera (accessed Jan. 2014)

62 http://www.julianwagstaff.com/breathefreelyprogramme.pdf (accessed Jan. 2014)

63 Smith, W. L. Thermodynamics, "Folk Culture and Poetry. J. Chem. Educ., 52, 1975, 97-98. 